\title{
Nas portas da guerra, o esplendor da humanidade
}

\author{
At the gates of war, the splendor of humanity
}

\author{
Renata dos Santos Ferreira*
}

ILLIES, Florian. 1913 - Antes da tempestade. $1^{\text {a }}$. ed. Tradução de Silvia Bittencourt. São Paulo: Estação Liberdade, 2016.

\begin{abstract}
David Starr Jordan, presidente da Universidade de Stanford, pronuncia em 1913 estas belas palavras: "A grande guerra europeia, uma ameaça eterna, jamais chegará. Os banqueiros não arranjarão dinheiro para tal guerra, a indústria não a manterá, os estadistas não terão como levá-la a cabo. Não acontecerá nenhuma grande guerra".
\end{abstract}

Os ventos da bonança pareciam soprar no ano de 1913. Pelo menos David Jordan pensava assim. Mas não apenas ele acreditava que a guerra na Europa não passaria de uma ameaça. Havia muita expectativa naquele início do século XX, afloravam as artes, as ciências, a tecnologia, os sonhos, as esperanças. Havia também certa melancolia, afinal, vislumbrava-se a possibilidade de uma guerra. Contudo, não se podia deixar de viver por causa disso. A modernidade eclodia em toda a sua pujança, foi um ano excepcional e vibrante para os movimentos de vanguarda artística. Nada seria como antes.

\footnotetext{
* Mestranda do Programa de Pós-Graduação em História da Universidade do Estado do Rio de Janeiro (PPGHUERJ). E-mail: rsanfer76@gmail.com.
}

(c) EY Direito autoral e licença de uso: Este artigo está licenciado sob uma Licença Creative Commons. Com essa licença você pode compartilhar, adaptar, para qualquer fim, desde que atribua a autoria da obra, forneça um link para a licença, e indicar se foram feitas alterações. 
Como traduzir essa atmosfera de sublimes perspectivas, de forma quase lúdica, às vésperas de uma tragédia jamais vista até então? Bastaria mergulhar naquele universo de amores, dores e artes, já tendo conhecimento sobre o destino dos personagens que habitavam as capitais europeias da cultura, Berlim, Munique, Viena e Paris, as mentes que criariam e revolucionariam o mundo em vários aspectos. $\mathrm{O}$ futuro era inevitável, mas promissor, apesar de todos os medos e angústias. Baionetas, trincheiras e aviões de guerra deveriam ser inimagináveis naquele contexto de civilização. Apenas pequenas aflições pessoais e impertinências políticas teriam razão de existir. A tensão provocada pelo expansionismo, as rivalidades entre Alemanha, França e Rússia e o choque de interesses econômicos e políticos das grandes potências mundiais industrializadas talvez não passassem de uma preocupação exagerada com meras disputas sem maiores consequências. Até que um estudante bósnio cometesse dois assassinatos em junho de 1914.

O historiador de arte formado em Bonn, jornalista e escritor alemão Florian Illies, nascido em 1971, naturalmente não teve a oportunidade de vivenciar os encontros, as paixões e os delírios daqueles sobre quem escreveu em 1913 - Antes da tempestade - sua intenção era registrar o ano de 1913 e tudo, ou quase tudo, que ele teve de magnífico, de original e transgressor. Produziu um best-seller internacional, que mais de um século depois revive uma Europa repleta de gênios e figuras extraordinárias que o tempo provou serem imprescindíveis para a humanidade. Definitivamente não era uma missão fácil, porém, bastante auspiciosa.

Proprietário de uma casa de leilões em Berlim e acostumado a negociar obras de arte, Illies é cofundador da revista Monopol e autor de outros quatro livros que juntos já venderam mais de um milhão de exemplares: Generation Golf: Eine Inspektion (Geração golfe: uma inspeção, 2000), que trata do conformismo da geração yuppie; Anleitung zum Unschuldigsein (Instruções para Unschuldigsein, 2001); Generation Golf zwei (Geração golfe II, 2003); e Ortsgespräch (Chamada local, 2006). Estudou por anos as vanguardas artísticas - música, literatura, artes plásticas -, diários, registros pessoais, biografias e textos jornalísticos para contar com certo humor como viviam e se aperfeiçoavam grandes talentos do século XX, nas suas prosaicas ações cotidianas, narradas mês a mês, em um formato que lembra as notas de colunas políticas ou de celebridades nos jornais, receita, aliás, para conquistar o leitor apressado da era da internet.

Paixões tórridas, separações, ímpetos criativos, progresso científico. Seguiam seu próprio caminho Franz Kafka, Thomas Mann, Marcel Proust, Virginia Woolf, Arthur Schnitzler, Igor Stravinski, Ludwig Wittgenstein, Pablo Picasso, Gertrude Stein, Henri Matisse, Rainer Maria Rilke, Sigmund Freud, Ernst Jünger, Carl Jung e tantos outros.... Até os jovens Hitler, Stalin e Tito caminhando pelo parque do Palácio de Schönbrunn buscavam um lugar ao sol 
(talvez tenham se cumprimentado algum dia). Parecia que toda a evolução e inteligência da humanidade - e também a sua desgraça - estavam reunidas naquele pedaço de mundo, o continente europeu às vésperas do conflito mundial que espreitava pelas frestas do horizonte e deixaria em seu rastro, cinco anos depois, mais de vinte milhões de mortos entre civis e militares.

Illies adota em 1913 um estilo de narrar inspirado na história do cotidiano, corrente nascida na França na década de 1960. Ainda que não utilize a perspectiva das pessoas comuns, como propõe essa abordagem, o escritor alemão explora não só eventos extraordinários, mas também fatos banais e momentos privados da rotina de personalidades que já eram famosas naquele momento, ou que viriam a ser um dia, com o objetivo de obter uma visão da realidade que os cercava. Afinal de contas, a história humana não se desenrola apenas nos gabinetes de autoridades e campos de batalha, ela se desdobra também nas pequenas ações cotidianas, que Michel de Certeau entendeu como reações contra a unidimensionalidade do mundo, reivindicação do espaço e do valor da particularidade e da individualidade numa sociedade cada vez mais massificada. $^{2}$

Trazer a público o comportamento, as atitudes, as obras e os discursos de grandes homens e mulheres, e ao mesmo tempo mostrar o quanto eles eram semelhantes aos seus contemporâneos, os cidadãos comuns que movem a grande máquina da humanidade, remete também a uma história das mentalidades, nos sentidos desenvolvidos por historiadores como Philippe Ariès, Michel Vovelle e Robert Mandrou.

Um desafio que se impunha a Florian Illies era conseguir atrair a curiosidade do leitor que tem poucas referências da Primeira Guerra, evento que redesenhou o mapa político da Europa e favoreceu a ascensão dos Estados Unidos à condição de primeira potência mundial. Numa época em que o apelo audiovisual exerce a supremacia sobre os interesses históricos do grande público, no imaginário popular ganha sempre em evidência a Segunda Guerra, incluindo alguns fatos que a antecederam, graças aos registros cinematográficos in loco, os filmes de campanha e aqueles realizados décadas após o fim do conflito, com as facilidades da tecnologia dos efeitos visuais e um maior conhecimento da história. A guerra se tornou um espetáculo rentável, mesmo passados tantos anos (vide o lançamento recente nos cinemas do espetacular Dunkirk, sobre a operação militar de resgate de soldados britânicos em Dunquerque, no início da Segunda Guerra), mas ainda são poucos os filmes ou programas de TV que traduzem o panorama e o horror da Primeira Guerra, com destaque para obras-primas filmadas antes ou durante a eclosão da grande guerra seguinte como A grande ilusão (1937), de Jean Renoir; Adeus às armas (1932), de Frank Borzage; Guerra, flagelo de Deus (1930), de Georg W. Pabst; e A Ponte de Waterloo (1940), de Mervyn LeRoy (uma curiosidade, a atriz britânica Vivien Leigh, que estrela esse drama romântico, nasceu em 1913). O 
filme A fita branca (2009), de Michael Haneke, com sua fotografia em preto e branco explora o clima angustiante numa pequena vila alemã às vésperas da Primeira Guerra. A intenção do diretor austríaco foi além de simplesmente mostrar a rotina de pessoas comuns à beira da tragédia, a trama busca sondar as origens do mal e da violência que iriam se apropriar da Alemanha sob a forma do nazismo.

1913 é um prato de fina degustação; seu estilo de narrativa, no lugar de empobrece-lo ou mediocrizá-lo, o torna mais aprazível na leitura, provoca excitação, desejo de saber o que virá pela frente. Lembra muito outro bestseller recente, Paris, a festa continuou: a vida cultural durante a ocupação nazista, 1940-4 (2012), ${ }^{3}$ do jornalista Alan Riding, que, com uma narrativa mais convencional, também investiga a vida cultural e o cotidiano de intelectuais e artistas na França ocupada pelos alemães durante a Segunda Guerra Mundial, com o agravante de terem que enfrentar o terror nazista que assassinou ou afugentou para outros cantos do mundo várias personalidades, entre artistas, pensadores e escritores.

Para Illies, encontrar um modo de fazer da história da cultura uma história agradável e envolvente, como declara em entrevistas de divulgação do livro ser seu intento, foi uma empreitada bem-sucedida: ganham os leitores que vão conhecer um momento fascinante e decisivo da história humana e seus contemporâneos; e ganha a história e os historiadores que trabalham para que os fatos, as ideias e os homens não sejam apenas poeira e esquecimento nas estradas deste mundo.

\section{Notas}

1 ILLIES, Florian. 1913 - Antes da tempestade. 1. ed. Trad. Silvia Bittencourt. São Paulo: Estação Liberdade, 2016. Orelha do livro.

2 CERTEAU, Michel de. A invenção do cotidiano: artes de fazer. Rio de Janeiro: Vozes, 1998.

3 RIDING, Alan. Paris, a festa continuou: a vida cultural durante a ocupação nazista, 19404. São Paulo: Companhia das Letras, 2012. 